\title{
RECENT REFORM OF CHINA'S RURAL LAND COMPENSATION STANDARDS
}

\author{
NELSON CHAN \\ University of Western Sydney
}

\section{ABSTRACT}

Since China adopted an open door policy in 1978, there has been rapid development in the economy and great improvement to the livelihood of the people. The rapid development also expedites urbanisation in the country. These forces have created great demand for land to support various developments. Compulsory acquisition of rural land has become a convenient means to increase land supply.

Compulsory acquisition of rural land is governed by the People's Republic of China Law of Land Administration 1998. This law also provides for the payment of compensation to dispossessed farmers. Land acquisition in recent years has encountered increasing resistance from farmers because of improper acquisition procedures and unfair compensation. In some cases, the resistance turns into violence and loss of human life.

In response to the serious problems, the Chinese government has since 2004 taken major steps, including amendment of the Constitution, to reform the land acquisition procedures and compensation standards. This paper aims to examine the latest development in the reform of compensation standards for acquisition of rural land in China. Recommendations for improvement are provided.

Keywords: Land acquisition, compensation disputes, compensation standards, constitutional amendment

\section{INTRODUCTION}

Since the introduction of the 'open door' policy in 1978, China has experienced rapid growth in socio-economic activities and population. It also leads to rapid urbanisation throughout the country. The government is under great pressure to supply more land to support relevant developments.

Despite that the government may squeeze some land through urban renewal schemes and compulsory land acquisition within the city areas, the amount of land obtained is far less Pacific Rim Property Research Journal, Vol 12, No 1 
than the amount required. In particular, local governments are competing against each other in recent years to establish development zones; the demand for land is at a record high. According to China Daily (2004a), as at March 2004, China has 500-600 development zones, covering a total of 3.55 million hectares. The land required is largely obtained from the acquisition of rural land. In fact, rural land accounts for about $90 \%$ of all compulsory land acquisition in China (Liu, 2002). It has been reported that China lost 6.7 million hectares of arable land between 1996 and 2003 (Xinhua News Agency, 2004b). This is roughly 97 times the size of Singapore or 42 times the size of the Sydney metropolitan area in Australia.

Apart from providing land for various developments, compulsory acquisition of rural land is also used by various governments to raise extra revenue. Although the amount of revenue raised through the land acquisition process is unknown, some indication can be obtained from land transfer figures. In Figure 1, it can be seen that land transfer revenue increased from Rmb 8.39 billion (approx. US\$1.04 billion) in 1993 to Rmb 27.97 billion (approx. US\$3.46 billion) in 2003, an increase of over 230\% over ten years.

\section{Figure 1: Land transfer revenue in China}

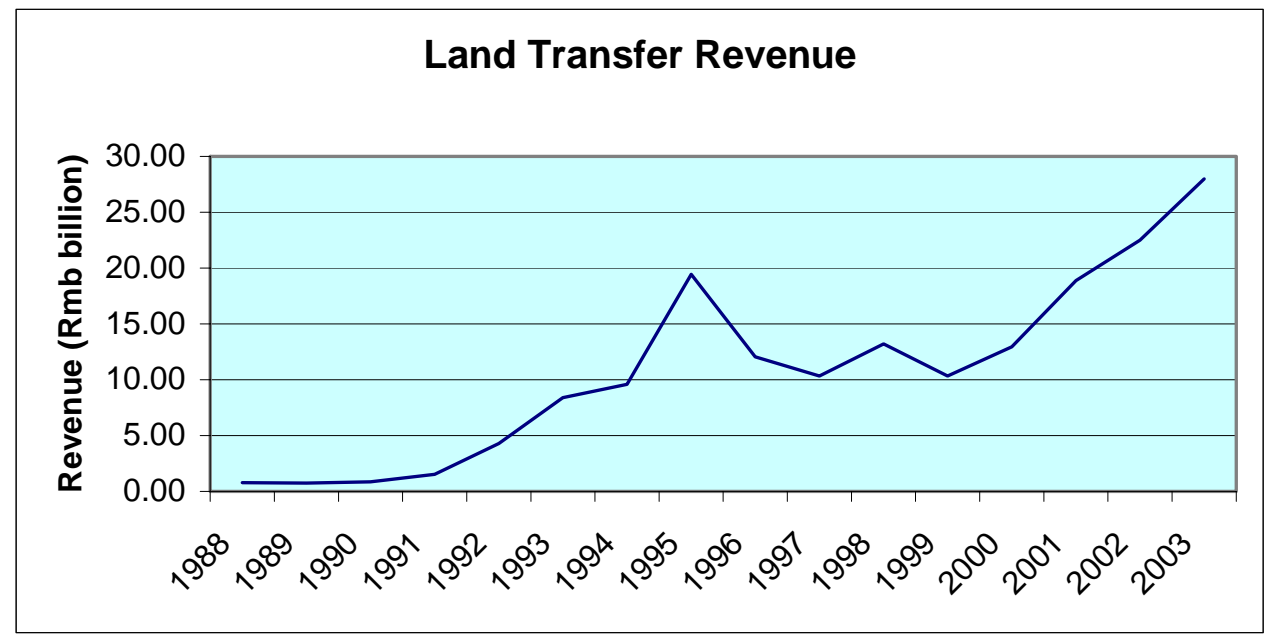

Data source: China Statistical Yearbooks 1997, 2000, \& 2004

In China, compensation is payable to farmers whose land has been compulsorily acquired. However, disputes over the acquisition procedure, unfair compensation and brutal treatment of dispossessed people have been increasing. According to Zhou \& Zhou (2004), the courts in Beijing only heard several hundred dispute cases before 1992. In 1999 , the number increased to 8,103 cases, and by 2001, the number increased to more than 15,000 cases. Disputes which are not satisfactorily solved frequently lead to petitions, violence, or even loss of human lives. In mid-June 2005, there was news about 
a compensation dispute in Dingzhou, Hebei Province that resulted in 10 deaths and nearly 100 injured (Lanfranco, 2005). The incident was reported widely in the media.

The ongoing serious problems have alerted the central government. Various measures have been introduced to reform the rural land acquisition procedure and compensation standards. This paper reviews the problems of the existing compensation standards and the various reform measures taken since 2004. Recommendations are made at the conclusion of the paper.

\section{EXISTING COMPENSATION STANDARDS}

The compensation standards for compulsory acquisition of rural land in China are provided in section 47 of the People's Republic of China Law of Land Administration 1986 as amended in 1998 (hereafter referred to as the "LLA"). It is supplemented by the People's Republic of China Law of Land Administration Implementation Regulation 1998 (hereafter referred to as the "LLAIR"). The compensation standards cover 3 areas:

1. compensation for the acquired land;

2. resettlement subsidy; and

3. compensation for crops and improvements on land.

Table 1 below summarises the compensation standards under the LLA.

Table 1: Rural Land Compensation Standards in China

\begin{tabular}{|c|c|}
\hline Item & Basis \\
\hline Principle of compensation & Original use of the land acquired \\
\hline Compensable items & $\begin{array}{ll}\text { 1. land compensation } \\
\text { 2. resettlement subsidy } \\
\text { 3. crops and improvements on land } \\
\text { compensation }\end{array}$ \\
\hline $\begin{array}{l}\text { Approach to assess land } \\
\text { compensation and resettlement subsidy }\end{array}$ & $\begin{array}{l}\text { A prescribed multiple of the average } \\
\text { annual production value of the land in the } \\
\text { preceding } 3 \text { years prior to acquisition }\end{array}$ \\
\hline $\begin{array}{l}\text { Prescribed land compensation multiplier: } \\
\text { 1. Arable land }\end{array}$ & 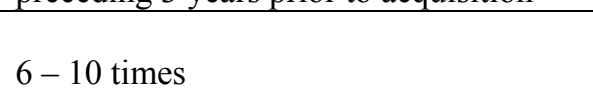 \\
\hline 2. Other land & $\begin{array}{l}\text { To be determined by respective level of } \\
\text { government }\end{array}$ \\
\hline Prescribed resettlement subsidy multiplier & $\begin{array}{l}4-6 \text { times for each person to be } \\
\text { resettled, subject to a maximum of } 15 \\
\text { times per hectare of land acquired }\end{array}$ \\
\hline $\begin{array}{l}\text { Crops and improvements on land } \\
\text { compensation }\end{array}$ & $\begin{array}{l}\text { To be determined by respective level of } \\
\text { government }\end{array}$ \\
\hline Maximum compensation multiplier in total & Not more than 30 times \\
\hline
\end{tabular}




\section{COMPENSATION STANDARDS - CHINA VS OTHER COUNTRIES}

On the face of it, the compensation standards have taken good care of the dispossessed farmers. A closer look reveals that it is not the case and does not give the farmers a fair deal. The basis for compensation is also questionable.

In many countries, the market value of the acquired land is used as a benchmark to assess the 'just' or 'reasonable' compensation. Although the meaning of 'just' or 'reasonable' compensation are not always defined in the relevant legislation, the compensation principle is aimed at putting, as far as money can do it, the dispossessed owner back to his or her original position as if there has been no acquisition (Brown, 2004; DenyerGreen, 2000). The market value of the acquired land is assessed on the basis of the potential (highest and best use) of the land.

In China, this compensation principle is not followed (Chan, 2003). Instead, it requires compensation to be based on the original use of the acquired land. It is interesting to see how the Chinese compensation standards are compared to those in other countries. Two countries, Australia and India, are chosen for comparison. Australia is a well developed country whereas India's pace of development is similar to China. Table 2 below summarises the differences.

\section{PROBLEMS OF CHINA'S COMPENSATION STANDARDS}

The comparison in Table 2 shows that China's compensation standards are very different from the other countries. The main problems of the Chinese compensation standards are analysed below:

\section{Compensation not based on common principle}

The market value compensation principle commonly adopted by other countries is not followed in China. Instead, the LLA stipulates that compensation has to be based on the original use of the acquired land. There are two major problems with this requirement.

Firstly, 'original use' is undefined. The LLA also does not clarify if it covers land that has been converted to non agricultural use. In the past two decades, a number of rural township enterprises and industries have sprung up from former rural land, i.e. the rural land may have been put to other profitable use prior to the compulsory land acquisition. An arbitrary interpretation of the meaning of 'original use' may lead to compensation that is based on the previous agricultural use of the land and cause significant hardship to the affected people. 
Table 2: Comparison of Compensation Standards in China, Australian and India

\begin{tabular}{|c|c|c|c|}
\hline Items & China & Australia & India \\
\hline Basis of land value & Original land use & Market value & $\begin{array}{l}\text { As per } \\
\text { Australia }\end{array}$ \\
\hline $\begin{array}{l}\text { Assessment of land } \\
\text { value compensation }\end{array}$ & $\begin{array}{l}\text { Based on a prescribed } \\
\text { multiple of the } \\
\text { average annual } \\
\text { production value of } \\
\text { the land in previous } 3 \\
\text { years prior to } \\
\text { acquisition }\end{array}$ & $\begin{array}{l}\text { Based on market } \\
\text { value of the land }\end{array}$ & $\begin{array}{l}\text { As per } \\
\text { Australia }\end{array}$ \\
\hline $\begin{array}{l}\text { Assessment of } \\
\text { resettlement payment }\end{array}$ & As above & $\begin{array}{l}\text { Covered by } \\
\text { consequential } \\
\text { financial losses }\end{array}$ & $\begin{array}{l}\text { Damage } \\
\text { sustained } \\
\text { by the } \\
\text { person } \\
\text { interested }\end{array}$ \\
\hline $\begin{array}{l}\text { Compensation for } \\
\text { Improvements on land } \\
\text { and crops }\end{array}$ & $\begin{array}{l}\text { To be determined by } \\
\text { respective level of } \\
\text { government }\end{array}$ & As above & As above \\
\hline Special value & No & Yes & No \\
\hline $\begin{array}{l}\text { Severance and } \\
\text { injurious affection loss }\end{array}$ & No & Yes & Yes \\
\hline $\begin{array}{l}\text { Other consequential } \\
\text { financial losses }\end{array}$ & No & $\begin{array}{l}\text { Yes, based on the } \\
\text { cost or loss incurred } \\
\text { by the claimant }\end{array}$ & $\begin{array}{l}\text { Yes, based } \\
\text { on damage } \\
\text { suffered by } \\
\text { the person } \\
\text { interested }\end{array}$ \\
\hline Extra payment & No & $\begin{array}{l}\text { Yes, an extra amount } \\
\text { (known as solatium) } \\
\text { specified in law }\end{array}$ & $\begin{array}{l}\text { Yes, an } \\
\text { additional } \\
30 \% \text { of the } \\
\text { market } \\
\text { value of the } \\
\text { acquired } \\
\text { land }\end{array}$ \\
\hline
\end{tabular}

Source: LLA, China; Lands Acquisition Act 1989, Australia; and The Land Acquisition Act 1894, India.

Secondly, a public use for which the land is acquired may not necessarily be a land use that has no general demand or market. The 'original use' compensation principle assumes that agricultural use is the highest and best use of all rural land. It excludes the possibility that rural land may have other more profitable uses, such as residential, 
commercial or industrial development.

The 'original use' principle may be introduced to reject claims for hope value that arises out of speculation. However, it is inequitable not to compensate for the loss of the land's intrinsic potential for more beneficial use that arises out of the land's physical characteristics and market forces. For example, it is natural and reasonable for farmland on the outskirt of a city to have a potential for non agricultural use. This potential should not be ignored in compensation assessment.

The British compulsory purchase legislation is more flexible in this regard. If the permitted existing use of the acquired land is agricultural, it allows the landowners to claim the highest and best use compensation on the assumption that planning permission would be granted for the intended land use of the authority's scheme (Denyer-Green, 2000).

\section{Compensation based on average annual production value}

Under section 63 of the LLA, rural land is not freely transferable. Accordingly, a rural land market does not exist and it is impossible to assess the market value of rural land (Ding, 2004). Instead of using market value as a basis for assessing compensation, the LLA provides that the compensation amount has to be based on the original use of the land. Following this principle, the land value is assessed by multiplying a prescribed multiplier from $6-10$ to the average annual production value of the acquired land in the preceding 3 years prior to the acquisition.

Although it is acceptable to value farmland on the basis of its productivity, the use of prescribed multipliers in compensation assessment has problems. Firstly, the basis for the multipliers is unknown. It is unsure what the constituent factors of the multipliers are. Even if the multipliers are well thought of and prepared with good faith, there is a big gap between the $6-10$ multipliers. The flexibility in choosing the multiplier can easily lead to corruption and cause grievance to dispossessed farmers.

Secondly, there is a problem of uncertainty in determining the annual production value of the acquired land. Agricultural production value is sensitive to adverse environmental impacts. Industrialisation of China has caused serious environmental problems. The extensive use of coal fuel has caused the formation of acid rain that covers one third of the nation. Zhang (1997) reported that the average annual $\mathrm{pH}$ value of the acid rain in Central China was below 4.0 and the frequency of acid rain was over 80 percent. Coupled with impacts from land degradation and natural disasters such as floods and droughts, the annual production value can be very low or even has a zero value. The average annual production value in the preceding 3 years can easily lead to a small sum of compensation.

Thirdly, the trend of a worldwide falling of grain prices also contributes to the uncertainty of production value. Increase in supply due to advances in farming 
technology has led to a fall in global grain prices. It has been reported that prices of wheat, soya bean and corn have fallen $30 \%, 42 \%$ and $35 \%$ respectively from their previous record high level (Wyatt, 2004). China has a long established agricultural policy of food self-sufficiency and farmers are encouraged to grow grains. This policy was reiterated in the Premier Wen Jiabao's government work report in March 2004 (Xinhua News Agency, 2004a). Unfortunately, grain prices in China also follow the global trend and have been falling since mid-1990s (Shi and Qi, 2004). Even if farmers are compensated at the highest multiplier of 30 , the compensation amount can still be very low.

\section{Unfair resettlement compensation}

The current provision for resettlement compensation is unfair. Firstly, the actual number of persons affected is not used to assess the amount of compensation. Instead, the LAA requires the number to be calculated by dividing the area of land acquired by the per capita land occupied by the dispossessed unit (village). It is apparent that the calculated figure may not necessarily match the number of persons actually affected by the acquisition.

Secondly, the payment is not based on the cost involved but on a prescribed multiple of the average annual production value of the land taken in the preceding 3 years prior to the acquisition. The pitfalls of the average annual production value approach were discussed above and are not repeated here. Since the actual resettlement cost is not adopted, the resettlement subsidy may not adequately cover the real cost incurred. Farmers may have to use their own money to subsidise the resettlement.

Thirdly, the subsidy is available only if the farmers are required to be resettled. If the land acquisition does not require resettlement, then the subsidy is not payable. In real life, farmers may have other consequential financial losses even no resettlement is required. As there is no statutory provision for compensating other consequential financial losses, the farmers have no way to recover the losses.

\section{Compensation for loss of improvements and crops}

The LLA requires the acquiring authority to compensate dispossessed farmers for the loss of improvements on the land and crops. However, it does not provide guidelines for compensation assessment. Instead, the relevant governments are authorised to make the decision. The absence of statutory guidelines has caused great disparity in compensation (Hu, 2004) and has become an issue of equity in compensation (Ding, 2004).

\section{No provision for damages from partial taking}

Sometimes a public scheme only needs to acquire a portion of the land. It may cause other land retained by the farmers to have value loss due to severance and/or injurious affection. "Severance damage is the depreciation in the value of the retained land caused by the loss of the resumed portion. Injurious affection is the depreciation in value 
of the retained land caused by actual or intended use of the portion resumed." (Brown, 2004, section 3.33)

The LLA does not cover land value loss due to severance and/or injurious affection. The affected farmers thus have no legal right to claim compensation in this regard. On the other hand, a partial land acquisition may not require the farmers to resettle elsewhere. As mentioned above, the farmers are not entitled to resettlement payment or compensation for other consequential losses.

\section{Compensation entitlement}

Under the current legislation, land compensation belongs to the rural collective concerned. Dispossessed farmers are only entitled to compensation for the loss of improvements on the land and crops which they owned. The life of the dispossessed farmers is made harder when the law requires the resettlement subsidy to be paid to the collective as well (LLAIR, clause 26). The law emphasises on unified resettlement programs and no guidelines are provided for the allocation of the compensation money. The real compensation received by the farmers can be very little. In a recent land acquisition in Shunyi district for a Beijing Olympic sports centre, the farmers complained that they would only receive a daily living subsidy of $0.90 \mathrm{Rmb}$ out of the resettlement payment (China Business, 2005).

Another problem lies in the lack of recognition of the farmers' legal interests in land under the current compensation law. The farmers' contractual right to cultivate the land is not a compensable item under the LLA. In the past two decades, the unfavourable living condition in rural areas has seen millions of farmers flocking to the cities for job opportunities. In order to keep their land cultivated under the contract, farmers sublet their land to other farmers within or outside their village. The current law has no provisions to compensate these subtenant farmers when the land is acquired.

\section{Unpaid compensation}

Under the LLA, the government has a monopolised power to convert farmland to construction land. Conversion of rural land to construction land through compulsory land acquisition is a lucrative process and is often used by various governments as a means to raise revenue. The lion's share of land value appreciation is taken by the government in the following manner:

a) government: $60-70 \%$;

b) village collective: $25-30 \%$; and

c) dispossessed farmers: less than $10 \%$

(Zhou \& Zhou, 2004)

Although farmers only have a small share, there is no guarantee that they will receive payment. The law requires the authority to pay the compensation amount within 3 months from the date the compensation and resettlement plan is approved (LLAIR, clause 25 , para. 4). However, the compensation money is often illegally retained by 
various government departments for private use. A recent investigation by the Ministry of State Land Resources reveals that, nationally, dispossessed farmers are owed Rmb 14.7 billion (approx. US\$1.8 billion) in land acquisition compensation money. So far the government has managed to pay the farmers Rmb 8.7 billion (approx. US\$1.1 billion) (Xie, 2004). It is unsure when the outstanding amount will be paid.

\section{No independent appeal channel}

Under clause 25, para. 3, of the LLAIR, the approving authority for the land acquisition is also the adjudicator for compensation disputes. There is no provision for the farmers to appeal to an independent tribunal or law court. Since the authority acts as the player as well as the referee in the game, there is clearly a conflict of interest. It is difficult to convince the farmers that they will be dealt with fairly.

\section{RECENT REFORM OF COMPENSATION STANDARDS}

The increasing number of compensation disputes and abuses of affected people has alerted the central government. In his Government Work Report 2004 to the National People's Congress (i.e. China' Parliament), Premier Wen Jiabao pledged, among other things, to ensure that appropriate compensation is paid for expropriated or requisitioned land (Xinhua News Agency, 2004a). Apart from pledging a review of compensation amount, the government also promises to take steps to solve the problems. The reform measures introduced since 2004 are analysed as follows:

\section{Land Acquisition Hearing System, January 2004}

In January 2004, the State Land Resources Hearing Regulation was introduced. It requires the authority to conduct a public hearing before a land acquisition scheme is carried out and the compensation payment is determined. China Daily (2004b) claims that, under this new requirement, no requisition of rural land will be approved without the endorsement of affected farmers. This claim is, however, untrue. The legislation only mentions about the procedure for conducting a hearing and says nothing about the need to have the farmers' endorsement prior to a land acquisition.

\section{Constitutional Amendment, March 2004}

In March 2004, the Chinese Constitution was amended for the $4^{\text {th }}$ time. In this round of amendment, 13 revisions were made. The revisions that have an impact on rural land compensation are listed in Table 3. 
Table 3: Relevant Revisions of the Chinese Constitution

\begin{tabular}{|c|l|l|}
\hline Article No. & \multicolumn{1}{|c|}{ Original Provision } & \multicolumn{1}{c|}{ Revised Provision } \\
\hline 10, paragraph 3 & $\begin{array}{l}\text { "The State may, in the public } \\
\text { interest, requisition land for its } \\
\text { use in accordance with the law." }\end{array}$ & $\begin{array}{l}\text { "The State may, in the public } \\
\text { interest and in accordance } \\
\text { with the provisions of law, } \\
\text { expropriate or requisition land } \\
\text { for its use and shall make } \\
\text { compensation for the land } \\
\text { expropriated or requisitioned." }\end{array}$ \\
\hline 13 & $\begin{array}{l}\text { "The State protects the right of } \\
\text { itizens to own lawfully earned } \\
\text { income, savings, houses and } \\
\text { other lawful property"; and "The } \\
\text { State protects according to law } \\
\text { the right of citizens to inherit } \\
\text { private property". }\end{array}$ & $\begin{array}{l}\text { "Citizens' lawful private } \\
\text { property is inviolable. The } \\
\text { State, in accordance with law, } \\
\text { protects the rights of citizens } \\
\text { to private property and to its } \\
\text { inheritance. The State may, in } \\
\text { the public interest and in } \\
\text { accordance with law, } \\
\text { expropriate or requisition } \\
\text { private property for its use and } \\
\text { shall make compensation for } \\
\text { the private property } \\
\text { expropriated or requisitioned." }\end{array}$ \\
\hline $\begin{array}{l}\text { 33, add new } \\
\text { paragraph 3 }\end{array}$ & $\begin{array}{l}\text { "The State respects and } \\
\text { preserves human rights." }\end{array}$ \\
\hline
\end{tabular}

The full force of the constitutional amendment is still to be seen. Nevertheless, it is certainly a big step forward. The revised Article 10 is most important and relevant to compensation for dispossessed farmers. Compensation for land acquisition is now a constitutional right of the dispossessed people (including farmers). However, the amended constitution does not define what public interest is. Unless the definition is provided in the relevant land acquisition law, governments at all levels are still free to make their own interpretation.

The amended Article 10 has another deficiency. It does not specify what compensation should be given. While it is the expectation of the general public that 'just' or 'reasonable' compensation should be given, Premier Wen Jiabao's Government Work Report 2004 makes it less clear. Instead of referring to 'just' or 'reasonable' compensation, he only pledged to ensure that the compensation is 'appropriate' (Xinhua News Agency, 2004a). It casts some doubt on the sincerity of the government to treat the dispossessed farmers fairly. 
China Daily (2004b) reports that the central government plans to increase the compensation amount by two to three times in the next few years. Presumably the proposed two to three times increment is deemed to be 'appropriate' compensation referred to in the Premier's report. However, even if the compensation is increased by that amount, it is unlikely that the amount is at a level comparable to the highest and best use value of the land taken. The problem of unfair compensation still remains unresolved.

Under the revised Article 13, it explicitly states that citizen's lawful private property is inviolable and that acquisition of private property has to be in public interest and in accordance with the provisions of law. Private property is not defined in the Constitution. It is reasonable to assume that it covers farmland as well. If this assumption is correct, then farmers' property rights in farmland cannot be violated and they have a legal right under this provision and Article 10 to challenge the legitimacy of a land acquisition proposal.

Human rights are now formally recognised and written into the Constitution. No doubt it is a breakthrough towards the improvement of human rights in China. Although the meaning of human rights is not defined in the Constitution, it is fair for the people to expect that reasonable land acquisition procedures and the right to receive 'just' or 'reasonable' compensation for land acquisition are within the ambit of this constitutional provision. However, the government's decision to give 'appropriate' compensation instead of 'just' or 'reasonable' compensation implies that farmers' human rights are still not fully recognised.

\section{Amendments to the LAA, August 2004}

On 28 August 2004, para. 4 of section 2 of the LLA was updated by the Standing Committee of the National People's Congress to "[t]he State may, in the public interest and in accordance with the provisions of law, expropriate or requisition land for its use and shall make compensation for the land expropriated or requisitioned" to match the wordings of the amended Article 10 of the Constitution. The word "requisition" in other relevant sections was replaced by "expropriate". In the past, the word "requisition" in Chinese could be interpreted in different ways and often caused disputes. The amendment helps remove the confusion.

These amendments are by no means thorough. The central government promises that a major amendment of the LLA will be carried out in the future after the introduction of the land administration system reform policy (Xinhua News Agency, 2004c).

\section{State Council's Decision, October 2004}

On 21 October 2004, the State Council issued a document "Decision on Deepening Reform and Strict Land Management Control" (hereafter referred to as the 'Decision'). As far as acquisition of rural land is concerned, Part 3 of the Decision provides for: 
a) perfecting the land acquisition compensation methods;

b) satisfactory resettlement of dispossessed farmers;

c) perfecting land acquisition procedure; and

d) strengthening the supervision of land acquisition process.

Items (a) and (b) are about improving the compensation standards. Item (a) requires various people's governments above county level to adopt real measures to ensure that the original living standard of dispossessed farmers will not be lowered because of the land acquisition. If this objective cannot be achieved even after compensation is paid at the prescribed maximum amount, the local people's government may pay additional subsidy from the state compensated land use revenue.

The other important initiative under item (a) is to require the people's government of various provinces, autonomous regions and municipalities to prepare and proclaim uniform annual production value standard or land acquisition zonal overall land value in various cities and counties. In addition, the 'same land, same value' principle has to be applied. This requirement is aimed at removing disputes on different compensation payments for adjoining land.

In order to prevent squeezing compensation amount for under-budgeted projects, item (a) requires that the compensation amount for national key construction projects has to be adequately allowed for in the budget. It appears that non national key construction projects may escape from this requirement.

Item (b) requires various people's governments above county level to take substantive measures to safeguard the long term livelihood of dispossessed farmers. For projects with stable return, farmers may use the land use rights of legally approved construction land to acquire shares of the projects.

If the acquired land is within a city plan area, the local people's government should include the landless farmers from the land acquisition into the city/town employment system, and to establish a social security system for them. If the acquired land is outside the city plan area, the local people's government should reserve necessary farmland or job vacancies for the dispossessed farmers. Landless farmers who do not meet the basic production life conditions should be resettled in different location.

Although item (b) provides more guidance for resettling the dispossessed farmers, it does not cover the allocation of resettlement money or require the rural collectives to distribute the resettlement payment to the farmers.

\section{Ministry of Land Resources' Instruction Opinion, November 2004}

The Decision only gives a framework on reforming land acquisition practice and does not provide operational details. On 3 November 2004, the Ministry of State Land Resource issue a document "Instruction Opinion on Perfecting the System of Land 
Acquisition Compensation and Resettlement" (hereafter referred to as the "Instruction Opinion') to provide further guidelines for implementing the requirements of the Decision. The more important aspects of this document are as follows:

The uniform annual production value standard should be determined with regard to the type and quality of the farmland, the farmers' investment on the farmland, crop prices, and the grading of the farmland. Again, it limits the maximum multiplier to 30 as stated in the LLA.

In relation to the preparation of land acquisition zonal overall land value, it should take into consideration the type of land, production value, location, grading of the farmland, per capita amount of farmland; relationship of supply and demand of land, local economic development level and minimum living standard of city/town residents.

It can be seen that, apart from production value, the zonal overall land value is also based on other factors such as location, supply and demand, and local economic development level, etc. It is a step closer towards the market value principle. However it misses the most important factor, i.e. the highest and use of the land. Wang (2005) reports that the government intends to use the zonal overall land value approach in medium to large cities and the uniform annual production value standard in less developed regions.

The Instruction Opinion allows rural collective economic units to allocate internally the land compensation money in a reasonable manner. The specific method of allocation is to be determined by various provincial people's governments. Where all land is acquired and the rural collective economic unit is dissolved, the land compensation money has to be totally used for the resettlement of the dispossessed farmers. Although the Instruction Opinion has given greater clarity for allocation of resettlement money, it fails to address the issue of distributing the compensation money to the farmers.

In relation to the resettlement of dispossessed farmers, free job skill training should be given to the farmers. The land use unit (i.e. the acquiring authority) should have priority in employing the farmers. This requirement may be met if the number of affected farmers is small. However, it is unlikely for the acquiring authority to provide jobs for thousands of farmers displaced from a particular land acquisition.

The Instruction Opinion also requires that, after the land acquisition compensation and resettlement plan has been approved by the city/county government, the compensation money has to be paid to the rural collective economic unit within the prescribed time limit. This requirement is not new and is already in the current law. Unfortunately, the time limit is often ignored and the compensation money is retained for other purposes; so this requirement remains a lip service. 


\section{Draft Property Rights Law, July 2005}

On 10 July 2005, the Law Committee of the National People's Congress released a draft law on Property Rights to the public for comments (People's Daily Online, 2005). The draft law aims to define and protect property rights of citizens. In regard to compulsory acquisition of contracted farmland, section 137 of the draft law stipulates that reasonable compensation has to be given. The contractor should be informed of the compensation standards and resettlement method.

For the acquisition of homestead land, section 163 requires the provision of a parcel of replacement land and the payment of compensation for damages caused. This is the first time that farmers' contractual rights and compensation entitlement are proposed to be written in law. However, until the draft law is passed and implemented, it remains a proposal.

\section{People's Supreme Court Interpretation, July 2005}

On 29 July 2005, the People's Supreme Court issued a document "Interpretation of Problems of Applicable Laws in Trials of Rural Land Contract Dispute Cases". The document specifies the categories of contract disputes that the people's courts should hear and support. Regarding compensation payment disputes, the courts support the contractor's right to:

a) require the contract issuing party to release the received compensation for improvement and crops;

b) require the contract issuing party to release the received resettlement payment if the family-contractor does not participate in the unified resettlement program;

The court will also support claims from a person who is a member of a rural collective economic unit at the time when the resettlement program was determined to require the unit to release his or her share of the land compensation payment. This is the second move in the reform to safeguard the contractual rights of farmers by giving them a legal channel to settle disputes. Unfortunately, the right to appeal only appears in this policy document of the Supreme Court. For more certainty, it needs to be written in the compensation law.

\section{Ministry of State Land Resources’ Notice, August 2005}

Further to the Instruction Opinion in November 2004, the Ministry of State Land Resources on 11 August 05 issued a document "Notice regarding the carrying out of work for preparing Uniform Annual Production Value Standard and Land Acquisition Zonal Overall Land Value" (hereafter referred to as the 'Notice'). The Notice urges relevant levels of government to complete the work for preparing the uniform annual production value standard and zonal overall land value, and have them proclaimed before the end of 2005. In addition, it emphasises: 
a) the protection of farmers' legal rights and ensuring their original living standard will not be lowered because of the land acquisition;

b) the implementation of the "same land, same value" principle such that the value of adjoining land will not be different because of the different purposes of land acquisition;

c) the coordination of equity principle such that compensation determined with uniform annual production standard matches that determined with the zonal overall land value approach; compensation under the new standards should not be less than that under the old standards; and

d) the implementation of the open hearing principle such that an open hearing for zonal land value is conducted according to legal requirements. Opinions from relevant government departments, rural collective economic units and farmers have to be taken into consideration.

\section{CONCLUSION}

The current compensation standards under the LLA for acquisition of rural land are unfair. The 'original use' compensation principle has seriously infringed the farmers' right to 'just' or 'reasonable' compensation. The uncertainty in assessing annual production value of the acquired land makes the compensation approach unacceptable. At present, about 2 million farmers lose their land every year and the number is increasing $(\mathrm{Hu}, 2004)$. The rising number of aggrieved farmers is a serious threat to community security. The solution to the problem is to give them a fair go.

Since 2004, the Chinese government has taken significant steps, amendment of the constitution, to improve the land compensation standards. No doubt the strict implementation of the various reform measures may help reduce the plight of farmers. Unfortunately, most of the measures are introduced as policy documents rather than written in law. It has seriously discounted the force of the reform. In addition, the uniform annual production value standard and land acquisition zonal overall land value are still being prepared. Exactly how much they will benefit the farmers is still to be seen.

At present, there is a huge gap between the compensation principle in China and other countries. The pace of development of India is similar to China, but she has a much fairer compensation system that is comparable to well developed countries. Being a developing country should not be used as an excuse by the Chinese government to treat the dispossessed farmers unfairly. In order to make the reform a success, the Chinese government needs to show more sincerity by carrying out more radical changes. In this regard, the following recommendations are worth considering: 
1. Scrapping the original land use compensation principle

The original land use compensation principle is unfair and has caused major discontent amongst dispossessed farmers. When the land acquired has a potential for more profitable uses, the highest and best use principle should be applied to assess reasonable compensation. The Chinese government may borrow the UK experience for improvement. There is no reason why farmers should not be allowed to claim what the land is worth. Farmers are traditionally at the bottom of the social hierarchy in China and are suffering most. They should be given a fair deal when they lose the land which is their lifeline.

2. Improving the annual production value compensation approach

The newly introduced uniform annual production value standard and zonal overall land value approach are an improvement. In the absence of compensation for loss of development potential, farmers can only rely on the new compensation approaches to get more benefit. Since the new approaches are linked to the production value of the land, the farmers may still suffer when they have three bad years before the acquisition or when crop prices drop.

To address the issue of uncertainty in annual production value, the authority may consider using the highest historic production volume of the land to assess the annual productive value, and, if necessary, to top it up by an ex-gratia payment. The maximum multiplier of 30 may also be relaxed when condition warrants the flexibility. These measures would help reduce the problems due to the uncertainty of annual production value.

3. Allowing consequential finance loss payment

Whether resettlement is needed for a land acquisition, the farmers affected are bound to have other consequential financial losses. The law should be amended to allow compensation for consequential financial losses in addition to resettlement subsidy.

Since farmers are not as well educated and knowledgeable as their fellow city citizens, they should be allowed and encouraged to get professional advice and assistance, and claim the cost under consequential loss compensation.

4. Introducing compensation for land value loss due to partial taking

The current compensation standards do not cover value loss of other retained land resulting from a partial taking, and affected farmers have no legal right to claim compensation for relevant losses. To make a fairer compensation system, claims for value loss of other retained land due to partial land acquisition should be allowed.

5. Making dispossessed farmers the payees of compensation

The current compensation law puts the dispossessed farmers in a very unfavourable position. Compensation for the acquired land is paid to the rural collectives instead 
of the farmers. Despite that the farmers may have lived and worked on the farm for generations, they are deemed to be tenants instead of owners of the land and do not have the right to receive compensation for losing the land.

The ideal solution is to have a radical change to the existing rural land ownership system and make the farmers owners of the land. Nevertheless, the change is a politically sensitive issue; the Chinese government is unlikely to change the status quo.

An alternative solution is to make it a legal requirement for direct payment of compensation money to the dispossessed farmers for the loss of the contractual right to cultivate the land. As far as subtenant farmers are concerned, they should also be compensated when the land is taken. Since they are the real persons cultivating the land on behalf of the absentee head-tenant farmers, it is fair for them to be compensated for the loss of crops, improvements on the land and the loss of contractual right to cultivate the land.

6. Guaranteeing payment to farmers

As mentioned above, dispossessed farmers are owed billions in compensation money. In order to prevent a recurrence of the problem, the government may consider setting up a statutory independent trust fund and require the acquiring authority to pay the compensation money into the fund prior to land acquisition. The trust then distributes the money to the dispossessed farmers.

To ensure the full amount of compensation money is deposited into the fund before the land acquisition, the trust should have the power to apply to the court for an injunction on behalf of the dispossessed farmers to stop the land acquisition until the full amount of compensation money is deposited into the fund.

7. Establishing proper appeal channel

At present, land acquisition disputes are adjudicated by the government approving the acquiring scheme. This arrangement is unfair and lack of trust from the people. Although the recent Supreme Court's policy document has touched upon this issue, it is still not enough. The legal right to appeal to an independent court or tribunal should be clearly written in the compensation law. It will safeguard the farmers' legal rights and reduce social unrest and corruption.

China has made significant economic progress in the past two decades. While the living standard of many people has improved, the majority of farmers are still struggling. The rapid development of the country has seen the acquisition of large amounts of rural land and the creation of millions of dispossessed farmers. The current compensation standards are far from satisfactory. The recent reform is aimed to give farmers a fairer go, and is a good beginning. However the strength of the reform is not sufficient. The above 
recommendations are by no means a panacea; nevertheless, their implementation would offer the farmers considerable relief.

\section{REFERENCES}

Lands Acquisition Act 1989 (Commonwealth), Australia.

Brown D., 2004, Land Acquisition: An examination of the principles of law governing the compulsory acquisition or resumption of land in Australia and New Zealand, $5^{\text {th }}$ edition, Butterworths.

Chan, N., 2003, Land Acquisition Compensation in China - Problems \& Answers, International Real Estate Review, Vol. 6, No. 1, pp. 136 - 152.

China Business, 2005, Beijing Olympic Project Land Acquisition Shunyi Dispute, 12 August, http://finance.sina.com.cn/g/20050812/2009262318.shtml.

China Daily, 2004a, CPPCC members call for rigid protection of cropland, 09 March, http://english.peopledaily.com.cn/200403/09/print20040309_136919.html

China Daily, 2004b, New Land Rule to Help Farmers, 10 February, http://www.

chinagate.com.cn/english/5090.htm

China Statistical Yearbooks 1997, 2000 \& 2004, http://210.72.32.26/index.htm.

Denyer-Green B., 2000, Compulsory Purchase And Compensation, 6th edition, Estates Gazette.

Ding, C., 2004, Effects of Land Acquisition on China's Economic Future, Land Lines, Vol 16, No. 1, pp. 11- 13.

Hu, C.M., 2004, Land Acquisition Reform to Protect Farmers' Rights, China Construction,

$\mathrm{http}: / /$ www.realestate.gov.cn/news.asp?recordno $=32441 \&$ teamno $=2 \&$ line $=111$

Lanfranco, E., 2005, Chinese officials purged after riot, The Washington Times, 15 June, United Press International, http://www.washtimes.com/upi/20050615-011043-5912r.htm

Liu, T.Z., 2002, The Management and Practice on Project Land Acquisition in China, http://www.chinaresettlement.com/conference/papers/tianzeng\%20liu--the $\% 20$ manageme.pdf. 
People's Daily Online, 2005, China solicits public opinions for revising draft law on property rights, 11 July, http://english.people.com.cn/200507/11/ eng20050711 195384.html

People's Republic of China Law of Land Administration 1986 (referred to as "LLA" in the text)

People's Republic of China Law of Land Administration Implementation Regulation 1998 (referred to as "LLAIR" in the text).

Shi, K. \& Qi, Y.J., 2004, Comments on the Third Amendment of Land Administration Law, Economic Reference News, http://www.realestate.gov.cn/news.asp?recordno $=3147 \&$ teamno $=2 \&$ line $=7$

The Land Acquisition Act 1894, India.

Wang, Y.H., (2005), Exploring The New Land Acquisition Compensation System, Ministry of State Land Resources, http://www.chinaccer.com/deart.asp?artid=40575

Wyatt, S., 2004, Growing Problems for China's Farmers, The Australian Financial Review, Thursday 5 August, p. 13.

Xie, D.K., 2004, Ministry of State Land Resources: Farmers are owed Rmb 14.7 billion land acquisition compensation payment, Xinhua News Agency, 24 August, $\mathrm{http}: / / \mathrm{www} \cdot$ realestate.gov.cn/Default.asp?recordno=37325\&teamno=1\&line $=1$.

Xinhua News Agency, 2004a, Report on the Work of the Government, Tuesday 16 March, http://english.peopledaily.com.cn/200403/16/eng20040316_137651.shtml

Xinhua News Agency, 2004b, China's farmland dwindles by $6 \mathrm{~m}$ ha in 7 years, 25 June, http://english.peopledaily.com.cn/200406/25/eng20040625_147555.html.

Xinhua News Agency, 2004c, Land Administration Law Amendment Bill revises Land Acquisition System, 25 August, http://house.people.com.cn/dichan/articule_04_08_ 25 2850.html.

Zhang H., 1997, Addressing pollution and ecological damage in China, China 2000, http://www.china2thou.com/9704p5.htm.

Zhou, Y. \& Zhou, K., 2004, Personnel from Ministry of State Land Resources undertaking Spring Sowing, China Business, http://www.realestate.gov.cn/news.asp? recordno $=32310 \&$ teamno $=2 \&$ line $=7$. 